\title{
Non-English Majored Freshmen's Perspectives on Benefits and Challenges of Using E-Learning: a Study at Van Lang University
}

\author{
Chau Thanh Nha, M.A.*, Hoang ThiHoa, M.A. \\ Van Lang University, Vietnam
}

*Corresponding Author: Chau Thanh Nha, M.A, Van Lang University, Vietnam.

\begin{abstract}
E-learning has been being used as a method of education around the globe.In the context of Vietnam, e-learning has been adopted during the COVID-19 pandemic; it, therefore, is still a new concept, especially among students. The study aimed to investigate students' perception of the benefits and challenges of using e-learning. The study was conducted at Van Lang University with the participation of 152 first-year students from different faculties. The quantitative research approach was employed in the study. The quantitative data collected from the questionnaire were processed by SPSS (19.0) The findings showed that several participants valued the advantages of e-learning. Particularly, students could study at their preferred time and place. It was easy for them to get access to the online materials, so they could get deeper understanding of the lessons. What is more, e-learning allowed students to study at their own pace. They, therefore, could review the lessons whenever they wanted so as to attain the objectives of each lesson. However, the study also found that students encountered some significant issues including low-speed connectivity to the Internet, technical problems, and loss of face-to-face interactions. The most interesting finding of the current study was that almost all participants could afford to purchase a computer, which was considered the major problem for the participants in previous studies.
\end{abstract}

Key words: benefits; challenges; e-learning; perspectives; Vietnamese context

Abbreviations: EFL: English as a Foreign Language; VLU: Van Lang University

\section{INTRODUCTION}

E-learning or electronic learning has been utilized to deliver the lectures to students who study from home, being away from schools and teachers. Thanks to the Internet, computers and other technological devices, students can access the online courses easily.

Since the first outbreak of Covid-19 was first identified in Wuhan, China in December 2019, the pandemic has been spreading all over the globe. It has been causing disastrous impacts on many aspects of society including economy, politics, etc., especially education. Vietnam is not an exception. Since the pandemic started in Vietnam in January 2020, education in Vietnam has changed a lot as a result. Many educational institutions have had different strategies for their training programs. Some allowed students to stay at home for a longer holiday whereas other schools carried out online learning courses for the students to avoid being behind the schedules. There have been a number of different perspectives on the effectiveness of online learning courses among parents and students because this is the first time that all of the courses have been completely delivered online, and Van Lang University (hereafter VLU) is an example. VLU students were asked to study online the whole second semester of the academic year 2020-2021. At first, there were many problems arising such as technical problems, difficulties related to new teaching-learning methods, etc., but later, the situation was more positively improved.

\section{Aims And ObJectives Of The Study}

In the second semester of the academic year 2020-2021, VLU students stayed home and had to join the online courses all the time via Microsoft Teams and get access to the coursework and materials on an open-course learning platform called Moodle. As lecturers of English teaching one of the courses to students at VLU, the authors realized that there have been many aspects that need to be discussed regarding the effectiveness of using e-learning. Therefore, the authors conducted a study with the aim of investigating the benefits and drawbacks of e-learning perceived by the first-year students at Van 
Lang University when attending the general English course online. Moreover, based on the findings, the study could make some valuable suggestions on how to improve the online learning policies and strategies at Van Lang University. Last but not least, this study is hoped to be the theoretical foundation for the future studies which are associated with the focus of this study. Therefore, the study mainly focused on answering the two following research questions:

Research Questions 1: What are the benefits and challenges of taking an online English course perceived by first-year students at Van Lang University?

Research Questions 2: What are practical suggestions on how to improve the quality of elearningcourses of English?

\section{LITERATURE REVIEW}

\subsection{Definitions of E-Learning}

E-learning is a complex concept covering a wide range of applications, learning strategies and processes (Rossi, 2009). It is, therefore, hard to propose a standard definition for the term "e-learning" (Oblinger\& Hawkins, 2005; Dublin, 2003). According to Fry (2001), e-learning is the way of combining the use of the Internet and other technological support and devices to publish materials for students to learn online, teach learners, and manage courses within an educational institution. Maltz et al. (2005) proposes that the term 'e-learning' is applied in different perspectives including distributed learning, online-distance learning, and hybrid learning as well.

\subsection{Benefits and challenges of E-Learning}

\subsubsection{Benefits of E-Learning}

According to Mohammadi et al. (2011), e-learning brings learners a lot of advantages as follows:

- It is a learner-centered teaching method in which teachers guide and facilitate students to reach the learning objectives.

- Students can learn at any time and in any place.

- It is a kind of cooperative learning.

- It helps students reduce the travel time and travel costs.

- It provides self-paced learning which allows students to learn at their own pace.

- It fosters the interaction between students and teachers, and among students.

- It is a comprehensive learning model; i.e., it contains all instructional sources and tools such as virtual classes and simulations.

- All activities such as enrolment, supervision, tuitions are done by Internet.

- Lessons are made and provided by different lecturers from different places.

- It allows learners to learn more than one major or specialty.

Raba (2005) states that the learning objectives can be reached easily in the short time without much effort. Teachers find it easy to prepare the lessons and students also find it simple to access the course materials because everything is available online and provided by experts in different fields of knowledge. Zhang et al. (2006) say that e-learning provides students with flexible learning ways, i.e. they do not need to attend the offline classes and also can watch or listen to the online lectures as many times as needed. Moreover, according to Brown et al. (2008) and Judahil et al. (2007), elearning allows teachers to interact with students in different ways in order to give them instant feedback.

\subsubsection{Challenges of E-Learning}

According to Collins et al. (1997), Scott et al. (1999), Lewis (2000), Almosa (2002), Marc (2002), Klein and Ware (2003), Akkoyuklu and Soylu (2006), and Hameed et al. (2008)there have been considerable disadvantages that both teachers and students may experience when using e-learning as a method of education: 
- English language learners may experience something unpleasant regarding contemplating the content of the lessons, being remote, lacking social interaction or relation when using e-learning.

- Teachers might find it hard to give clarifications, provide explanations, offer interpretations because of the face-to-face encounter between teachers and students.

- All the tests are done online, so teachers cannot control students' bad behaviors or activities namely cheating or plagiarism.

- For the subjects which require practices, e-learning may hinder learners from developing practical skills, such speaking skills.

- Congestion or heavy use of some networking sites is not avoidable. This may be time-consuming

Ghaffari and Abbas (2011) highlight the significant drawback of e-learning which hampers face-toface interaction among teachers and students. In addition, Jenkinson (2009) claims that the most formidable obstacles for the utilization of e-learning consist of being overpriced to conduct, new skills needed such as technical skills, students' financial conditions, and loss of face-to-face or social interactions.

\section{Previous Studies}

Many studies have been conducted to answer the question regarding the effectiveness of adopting ELearning in teaching and learning English.

Johan et al. (2013) conducted a study to investigate the effectiveness of using E-learning with the participation of 45 students studying at three schools in Shah Alam, Selangor. A questionnaire was utilized to collect quantitative data and the data were analyzed using by SPSS 19.0. The findings showed that most of the participants preferred to learn via E-Learning because it allowed them to choose either instructor-led or self-study courses and the students were flexible to learn at any place and time. However, lack of face-to-face interactions among friends was considered the major shortcoming in the e-Learning process.

Al-Maqtri (2014) tested the utilization of e-learning platform by English tutors in Saudi Arabia's King Khalid University. The results showed that all students considered the adoption of e-learning in learning English ineffective. They did not feel motivated to learn by using e-learning platform because of the inaccessibility to the Internet which was the most perceived shortcoming.

Khan (2016) examined the effectiveness of using e-learning in teaching English. Khan also learned about how effective the application of e-training was for teachers as well as the utilization of eresources. The findings revealed that employing e-learning in teaching English was highly valued. Moreover, e-resources also caught students' attention including passive students.

Laxmi (2017) studied students' perceptions of online learning platforms in EFL classroom. There were 40 participants answering questions from the questionnaires and interviews. The mixed methods approach was employed to analyze the data. Despite the fact that low-speed connectivityto the Internet was regarded as the gravest difficulty, almost all students acknowledged that online learning platforms could assist them in practicing language skills, learning more lexis and expanding their understanding about the content delivered in the lessons.

Mohammed (2020) carried out a study on challenges and benefits of using e-learning among EFL students in Bisha University in Saudi Arabia. The research involved 36 faculty members and 261 undergraduates. The questionnaires were utilized to collect the data. The results showed that students valued the advantages of using e-learning in terms of possibility, availability, and conductibility. However, students also suffered from some potential shortcomings including academic, technological and administrative challenges.

Henny (2020) investigated the use of e-learning to teach English in the time of the Covid-19 pandemic. The descriptive qualitative research approach was employed to collect and analyze the data. The findings showed that it was easy for both teachers and students to get access to the Internet from home and work together. Nevertheless, the shortcomings were also highlighted in the study 
namely the unavailability of the Internet access, the lack of motivation, the absence of face-to-face or psychological interactions.

\section{RESEARCH METHODOLOGY}

\subsection{Research Setting}

This study was conducted at Van Lang University at \#45, Nguyen KhacNhu Street, Co Giang Ward, District 1, Ho Chi Minh City, Vietnam. Due to the coronavirus pandemic, all of the training programs of the second semester of the academic year 2020-2021 at VLU were implemented online. Students attended the livestreaming classes via Microsoft Teams application and did a large number of assignments on Moodle (Learning Platform managed by Van Lang University).

With regard to the general English course, besides attending the livestreaming classes with the teacher within 45 periods, the students were required to complete the work and assignments on Moodle. The livestreaming classes were recorded and posted on Moodle so that the students could watch the lectures again whenever they wanted.

\subsection{Sample and Sampling}

The convenience sampling strategy was employed in this study because it concerns "a group of individuals that is ready and available" (Fink, 1995, p. 67). Therefore, the authors could select the participants easily and conveniently. Moreover, the authorsare full-time lecturers at Van Lang University and have just finished teaching some groups of non-English majored freshmen, so it is much more convenient for the authors to collect the data. The participants in the present study consisted of 152 non-English majored freshmen (50 males and 102 females) from different faculties at VLU as presented in Figure 5.1.

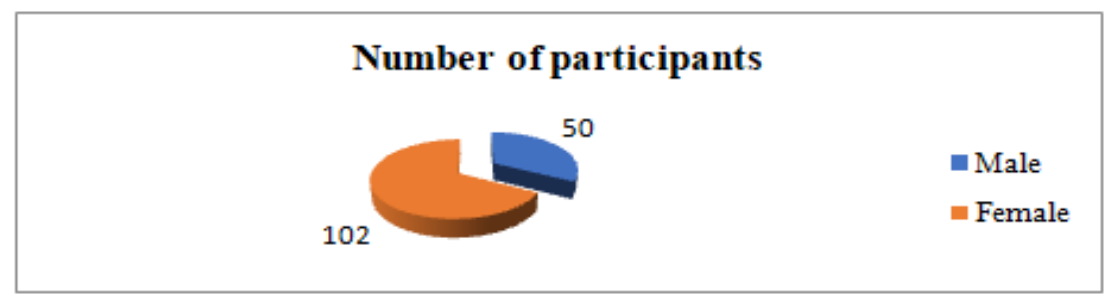

Figure5.1. Number of Students Participating in the Study

VLU students have a wealth of background knowledge of computer. As can be seen in Figure 5.2, all students can use a computer at elevated levels from "good" to "excellent". In particular, 78 out of 152 students can work with computer very well. 59 students are good enough to use a computer. Interestingly, 15 students consider themselves expert in technology.

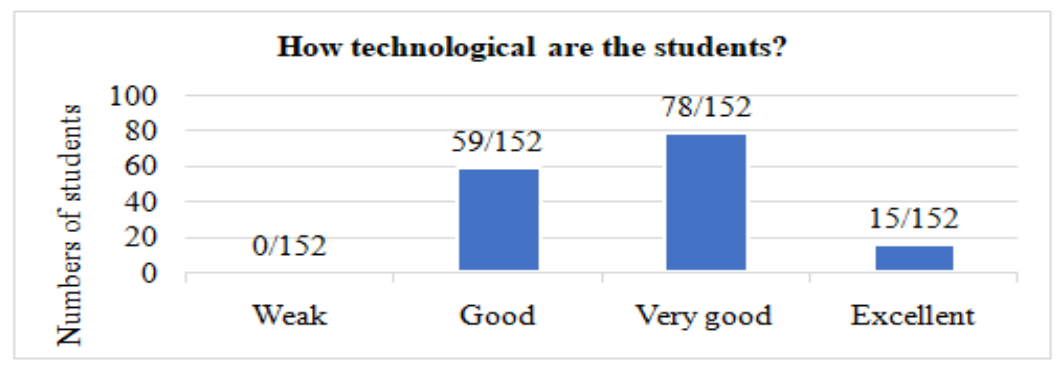

Figure5.2. Students' competency in using a computer

In addition, only 16 out of 152 students (about 10\%) do not have a computer whilst 136 students (about $90 \%$ ) have their own computers as displayed in Figure 5.3. 


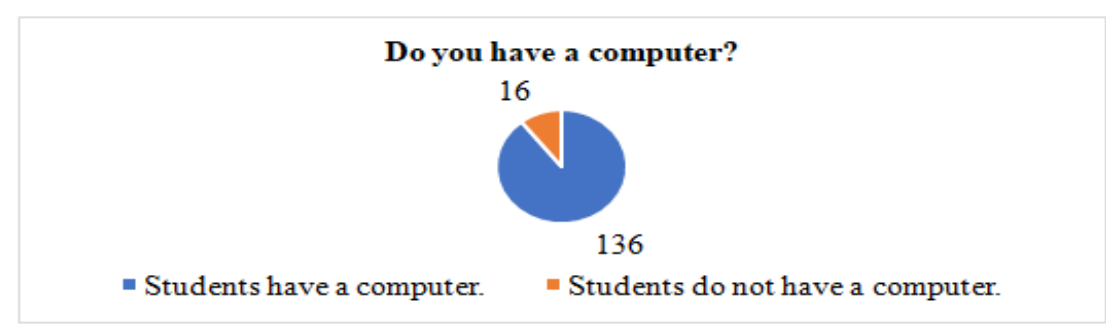

Figure5.3. Number of students who have and do not have a computer

Moreover, the vast majority of the participants have the Internet access at home whereas there are 2 students who cannot use the Internet at home, as presented in Figure 5.4.

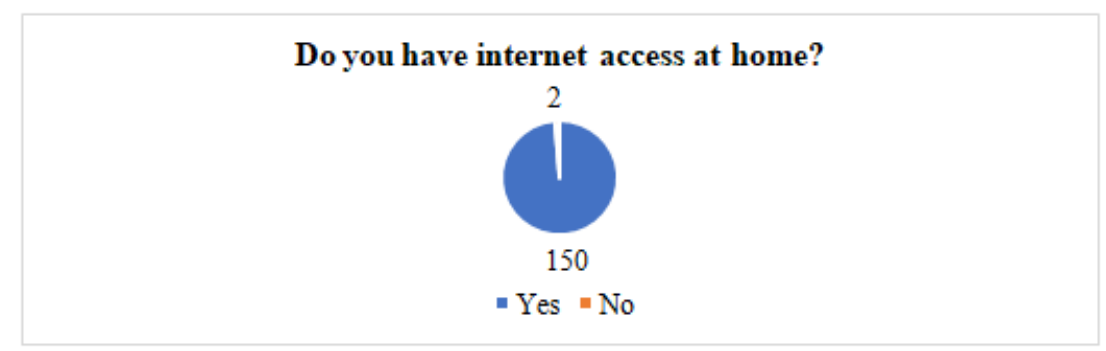

Figure5.4. Number of students who have or do not have the Internet access at home

Figure 5.5 presents students' preferencesregarding learning environments. Most of the students prefer to use the Internet for e-learning at home. Among 152 participants in this study, there are 18 students who enjoy learning at a cybercafé and 15 students who like to stay at school to attend e-learning classes.

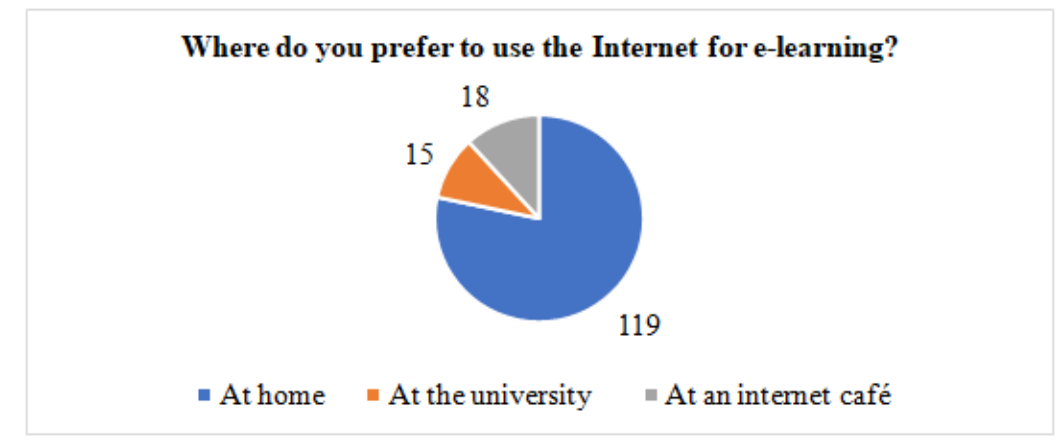

Figure5.5. Where students prefer to use the Internet for e-learning

When being asked whether they agreed with the statement "e-learning is a waste of time", 147 out of 152 participants answered "No" to the question. It can partially conclude that the students have acknowledged the importance of e-learning in the current circumstance.

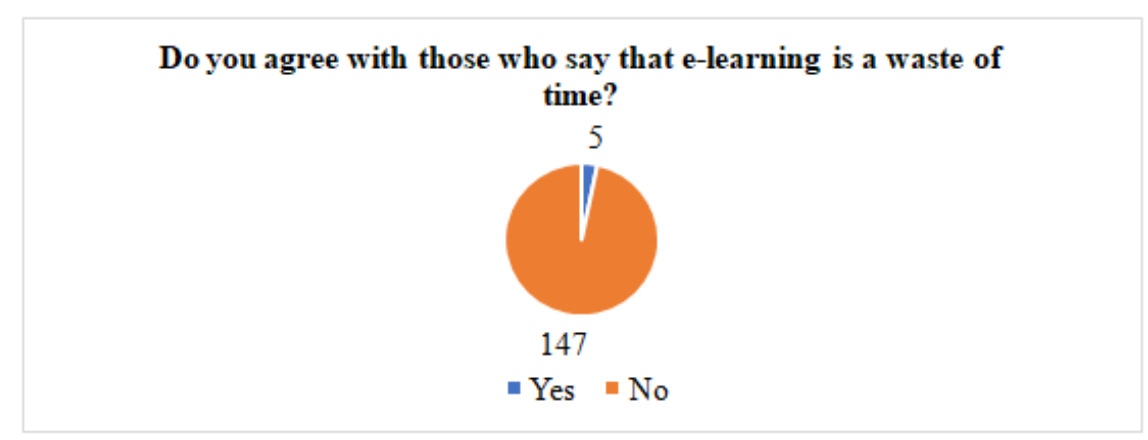

Figure5.6. Students' perceptions of e-learning as a waste of time

On balance, most of the participants are quite expert in using a computer. Besides they are able to afford a computer and have the Internet access at home. Nearly all of them are aware of the necessity of e-learning in this lean period. 


\subsection{Research Design}

The quantitative research approach was employed in the present study. Concerning the quantitative research method, according Bryman (2001), the quantitative research method focuses on the work with numbers or figures in data collection and analysis and can be regarded as being scientific in nature. This research method is more connected to the objectivities and validities of what has been observed or surveyed. The size of the involved sample is often large (Babbie, 1989; Bogdan \& Biklen, 1992). An important factor of this research method is that both descriptive and analytical summaries can be combined in the process of data collection (Smith, 1994). The hypotheses and theories of the studies are tested with the use of the qualitative research.

\subsection{Research Instrument}

Aquestionnaire which was designed with the application of Google form survey was used to collect quantitative data.

Most data in quantitative research can be collected by means of questionnaires (Smith, 1994). The questionnaires can be mailed or administered to the respondents, so it saves time and money (Gay, 1987; Borg \& Gall, 1989). Bell (2003) points out that a questionnaire is essentially considered a structured approach for collecting primary data. Therefore, a series of questions is prepared to get the answers from the respondents.

The questionnaire in the present study was adapted from two studies: the studies of Abdul at el. (2013), and Nur (2014). The reason for this choice was because the authors have realized that the questionnaires employed in these studies have had most of the features in common with the related literature that the author reviewed.

The questionnaire consists of two parts. In Part I, students were asked to provide some general information including their age range, technological skills, internet access possibility, etc. (see the appendix). In Part II, there are 16 close-ended questions regarding the advantages and limitations of elearning as well as suggestions for improvement. In order to answer the questions in Part II, the participants were asked to choose the appropriate level for five close-ended items designed in 5-point Likert scale $(1=$ strongly disagree, $2=$ disagree, $3=$ undecided, $4=$ agree, $5=$ strongly agree) (See the appendix).

\subsection{Validity and Reliability}

The English questionnaire was first written and then translated into Vietnamese, which helped participants understand the items better and more easily. Moreover, English questionnaire was checked by two Vietnamese experts who are the authors' colleagues and are the experienced researchers. More importantly, in order to increase reliability, validity and practicality, a pilot study had been done before the main study was conducted. Piloting questionnaire not only helps to improve quality, but also demonstrates increased reliability in the research process (Oppenheim, 1992; Radhakrishna, 2007; Seliger\&Shohamy, 1997). Therefore, the authors chose 20 students to participate in the pilot study before conducting a large-scale survey. Besides, through the pilot, the author realized how well the participants understood the content of the translated version. Fortunately, the questions were well-understood by all the participants, and there were no corrections or modifications then. More worthily, the reliability of the questionnaire was quantitatively computed by SPSS to produce Cronbach's Alpha Coefficients. The Cronbach's Alpha coefficients used in the present study to measure the reliability were set by George and Mallery (2003) including unacceptable: $\alpha<0.500$; poor: $0.500<\alpha<0.600$; questionable: $0.600<\alpha<0.700$; acceptable: $0.700<\alpha<0.800$; good: 0.800 $<\alpha<0.900$; and excellent: $0.900<\alpha$. The reliability of the variables in the second section of the questionnaire was measured. The second section included 16 items regarding the advantages ( 8 items) and disadvantages ( 8 items) of E-Learning. The reliability result, quantitatively computed by SPSS, was .88 , and .80 respectively, as respectively presented in Tables 1 and 2.

Table1. Reliability Statistics on the Items Regarding the Benefits of E-Learning

\begin{tabular}{|l|l|}
\hline Cronbach's Alpha & N of Items \\
\hline .88 & 8 \\
\hline
\end{tabular}

Table2. Reliability Statistics on the Items Regarding the Challenges of E-Learning 
Non-English Majored Freshmen's Perspectives on Benefits and Challenges of Using E-Learning: a Study at Van Lang University

\begin{tabular}{|l|l|}
\hline Cronbach's Alpha & N of Items \\
\hline .80 & 8 \\
\hline
\end{tabular}

In conclusion, the results of reliability statistics presented in Tables 1 and 2 have showed that the questionnaire was reliable enough to be used for collecting quantitative data.

\subsection{Ethical Issues}

During the survey, participants' personal information was kept confidential. Moreover, the authors explained about the objectives of the study and sought for their enthusiasm and willingness to participate in answering questions. Moreover, participants were also informed that they had the right to refuse or agree to participate in the study at any time they wanted.

\section{FINDINGS AND DISCUSSIONS}

The data were analyzed in terms of the percentage $(\mathrm{P})$ of each point in response to each item. The data that belonged to the scales "strongly disagree" and "disagree" were merged together. The merged data were marked as "the disagreed side". Likewise, the data that belonged to the scales "agree" and "strongly agree" were merged together. The merged data were labelled as "the agreed side".

\subsection{Benefits of Using E-Learning as A Method of Education}

Table3. Results Regarding Students' Perspectives on Advantages of E-Learning(n=152)

\begin{tabular}{|c|c|c|c|c|c|c|}
\hline No & Items & $\begin{array}{l}\text { Strongly } \\
\text { disagree }\end{array}$ & Disagree & Undecided & Agree & $\begin{array}{l}\text { Strongly } \\
\text { Agree }\end{array}$ \\
\hline \multirow[b]{2}{*}{1} & \multirow{2}{*}{$\begin{array}{l}\text { E-learning enables learning at any time } \\
\text { and place. }\end{array}$} & \multicolumn{2}{|l|}{$P=4.6 \%$} & \multirow[b]{2}{*}{$\begin{array}{l}31 \\
P=\mathbf{2 0 . 4 \%}\end{array}$} & \multicolumn{2}{|c|}{$P=75.0 \%$} \\
\hline & & $\begin{array}{l}2 \\
1.3 \%\end{array}$ & $\begin{array}{l}5 \\
3.3\end{array}$ & & $\begin{array}{l}70 \\
46.1 \%\end{array}$ & $\begin{array}{l}44 \\
28.9 \%\end{array}$ \\
\hline \multirow[b]{2}{*}{2} & \multirow{2}{*}{$\begin{array}{l}\text { An English E-learning course makes } \\
\text { teaching and learning more effective } \\
\text { because it combines all forms of } \\
\text { materials such as media, printable } \\
\text { resources, audios, videos, etc. }\end{array}$} & \multicolumn{2}{|l|}{$P=3.9 \%$} & \multirow[b]{2}{*}{$\begin{array}{l}37 \\
P=\mathbf{2 4 . 3 \%}\end{array}$} & \multicolumn{2}{|c|}{$P=71.7 \%$} \\
\hline & & $\begin{array}{l}2 \\
1.3 \%\end{array}$ & $\begin{array}{l}4 \\
2.6 \%\end{array}$ & & $\begin{array}{l}74 \\
48.7 \%\end{array}$ & $\begin{array}{l}35 \\
23.0 \%\end{array}$ \\
\hline \multirow[b]{2}{*}{3} & \multirow[b]{2}{*}{$\begin{array}{l}\text { I like e-learning because I can work } \\
\text { following my own pace. }\end{array}$} & \multicolumn{2}{|l|}{$P=6.6 \%$} & \multirow[b]{2}{*}{$\begin{array}{l}39 \\
P=\mathbf{2 5 . 7 \%}\end{array}$} & \multicolumn{2}{|c|}{$P=67.7 \%$} \\
\hline & & $\begin{array}{l}3 \\
2.0 \%\end{array}$ & $\begin{array}{l}7 \\
4.6 \%\end{array}$ & & $\begin{array}{l}73 \\
48.0 \%\end{array}$ & $\begin{array}{l}30 \\
19.7 \%\end{array}$ \\
\hline \multirow[b]{2}{*}{4} & \multirow{2}{*}{$\begin{array}{l}\text { An English e-learning course helps me to } \\
\text { develop knowledge of computer and } \\
\text { internet. }\end{array}$} & \multicolumn{2}{|l|}{$P=6.0 \%$} & \multirow[b]{2}{*}{$\begin{array}{l}40 \\
P=\mathbf{2 6 . 3 \%}\end{array}$} & \multicolumn{2}{|c|}{$P=67.8 \%$} \\
\hline & & $\begin{array}{l}1 \\
0.7 \%\end{array}$ & $\begin{array}{l}8 \\
5.3 \%\end{array}$ & & $\begin{array}{l}79 \\
52.0 \%\end{array}$ & $\begin{array}{l}24 \\
15.8 \%\end{array}$ \\
\hline \multirow[b]{2}{*}{5} & \multirow[b]{2}{*}{$\begin{array}{l}\text { I feel more confident when I use English } \\
\text { in an online class than in an offline class. }\end{array}$} & \multicolumn{2}{|c|}{$P=12.5 \%$} & \multirow[b]{2}{*}{$\begin{array}{l}47 \\
\mathbf{P}=\mathbf{3 0 . 9 \%}\end{array}$} & \multicolumn{2}{|c|}{$P=56.6 \%$} \\
\hline & & $\begin{array}{l}5 \\
3.3 \%\end{array}$ & $\begin{array}{l}14 \\
9.2 \%\end{array}$ & & $\begin{array}{l}57 \\
37.5 \%\end{array}$ & $\begin{array}{l}29 \\
19.1 \%\end{array}$ \\
\hline \multirow[b]{2}{*}{6} & \multirow[b]{2}{*}{$\begin{array}{l}\text { Taking an English E-learning } \\
\text { coursehelps me to use time effectively. }\end{array}$} & \multicolumn{2}{|l|}{$P=5.9 \%$} & \multirow[b]{2}{*}{$\begin{array}{l}46 \\
P=30.3 \%\end{array}$} & \multicolumn{2}{|c|}{$P=63.8 \%$} \\
\hline & & $\begin{array}{l}4 \\
2.6 \%\end{array}$ & $\begin{array}{l}5 \\
3.3 \%\end{array}$ & & $\begin{array}{l}71 \\
46.7 \%\end{array}$ & $\begin{array}{l}26 \\
17.1 \%\end{array}$ \\
\hline \multirow[b]{2}{*}{7} & \multirow[b]{2}{*}{$\begin{array}{l}\text { E-learning helps me to get access to } \\
\text { authentic English language materials. }\end{array}$} & \multicolumn{2}{|l|}{$P=6.6 \%$} & \multirow[b]{2}{*}{$\begin{array}{l}45 \\
P=\mathbf{2 9 . 6 \%}\end{array}$} & \multicolumn{2}{|c|}{$P=63.8 \%$} \\
\hline & & $\begin{array}{l}2 \\
1.3 \%\end{array}$ & $\begin{array}{l}8 \\
5.3 \%\end{array}$ & & $\begin{array}{l}74 \\
48.7 \%\end{array}$ & $\begin{array}{l}23 \\
15.1 \%\end{array}$ \\
\hline \multirow[b]{2}{*}{8} & \multirow{2}{*}{$\begin{array}{l}\text { I benefit from the feedback given by my } \\
\text { instructor through MS Teams or Moodle. }\end{array}$} & $P=4.0 \%$ & & & $P=80$ & \\
\hline & & $\begin{array}{l}5 \\
3.3 \%\end{array}$ & $\begin{array}{l}1 \\
0.7 \%\end{array}$ & $P=15.1 \%$ & $\begin{array}{l}79 \\
52.0 \%\end{array}$ & $\begin{array}{l}44 \\
28.9 \%\end{array}$ \\
\hline
\end{tabular}

$(P=$ percentage $)$

As showed in Table 3, more than 50\% of the participants acknowledged the advantages of e-learning. In particular, $75 \%$ of the students found e-learning convenient because they could learn at any time and in any place (Item 1). Moreover, 109 out of 152 students (Item 2, P=71.7\%) agreed that e-learning made teaching and learning more effective because they were able to be well-equipped with a lot of sources of materials such as videos, printable resources, audios, etc. What is more, e-learning allowed students to study at their own pace, when they did not understand the contents, they could study again and again (Item 3, P=67.7\%). For those who were not good at using computers and the Internet, after a course of e-learning, they could significantly improve their technical skills (Item 4, $\mathrm{P}=67.8 \%$ ). 
Non-English Majored Freshmen's Perspectives on Benefits and Challenges of Using E-Learning: a Study at Van Lang University

Furthermore, more than $50 \%$ of the respondents to the questionnaire felt more confident to use English via a virtual classroom than in a traditional classroom (Item 5, P=56.6\%). In addition, taking an English e-learning course helped students control their time effectively (Item 6, P=63.8\%). Additionally, 97 out of 152 students (Item 7, P=63.8\%) agreed that e-learning allowed them to get access to authentic English language materials such as online newspapers reporting what have recently happened around the globe. Last but not least, Microsoft Teams and Moodle were the two effective teaching and learning platforms where teachers and students could have the livestreaming classes, discuss the learning topics, give and receive feedback as well as the learning outcomes (Item $8, \mathrm{P}=80.9 \%$ ). In conclusion, most of the research participants had the positive perceptions towards the advantages of adopting e-learning in learning English.

The current study found that students considered e-learning convenient since they could choose when to learn and where to learn. This finding further supports the idea of Mohammadi et al. (2011) who acknowledge that e-learning allows students to study at any time and any place. In other words, elearning provides students with flexible ways (Zhang et al., 2006). In a same vein, it is encouraging to compare this figure with that found by Johan et al. (2013)who found that the participants preferred to learning via e-learning since it allowed them to choose either instructor-led or self-study courses and be flexible to learn at their preferred time and place.

Another important finding was that the effectiveness of using e-learning was demonstrated through a wealth of e-resources which have been easily accessible to the students. This result matches with that observed in earlier studies.For example, Khan (2016) found that online resources captured students' attention including passive students.

Other significant findings were that learning outcomes could be improved since students could learn at their own pace and review the lesson at any time. In accordance with the present results, previous studies have demonstrated that e-learning platforms assisted students in practicing language skills, learn more vocabulary and expanding their understanding about the content delivered in the lesson (Laxmi, 2017), and students highly valued the benefits of using e-learning in terms of possibility, availability and conductibility (Mohammed, 2020).

\subsection{Challenges of Using E-Learning as a Method of Education}

Table4. Results Regarding Students' Perspectives on Challenges of E-Learning $(n=152)$

\begin{tabular}{|c|c|c|c|c|c|c|}
\hline No & Items & $\begin{array}{l}\text { Strongly } \\
\text { disagree }\end{array}$ & Disagree & Undecided & Agree & $\begin{array}{l}\text { Strongly } \\
\text { Agree }\end{array}$ \\
\hline \multirow[b]{2}{*}{1} & \multirow[b]{2}{*}{$\begin{array}{l}\text { E-learning is difficult to handle and } \\
\text { therefore frustrating to use. }\end{array}$} & \multicolumn{2}{|l|}{$P=54.6 \%$} & \multirow[b]{2}{*}{$\begin{array}{l}48 \\
P=31.6 \%\end{array}$} & \multicolumn{2}{|c|}{$P=13.8 \%$} \\
\hline & & $\begin{array}{l}19 \\
12.5 \%\end{array}$ & $\begin{array}{l}64 \\
42.1 \%\end{array}$ & & $\begin{array}{l}19 \\
12.5 \%\end{array}$ & $\begin{array}{l}2 \\
1.3 \%\end{array}$ \\
\hline \multirow[b]{2}{*}{2} & \multirow[b]{2}{*}{$\begin{array}{l}\text { Slow internet connectivity is a major } \\
\text { problem I face when using e-learning. }\end{array}$} & \multicolumn{2}{|c|}{$P=15.2 \%$} & \multirow[b]{2}{*}{$\begin{array}{l}22 \\
P=14.5 \%\end{array}$} & \multicolumn{2}{|c|}{$P=70.4 \%$} \\
\hline & & $\begin{array}{l}8 \\
5.3 \%\end{array}$ & $\begin{array}{l}15 \\
9.9 \%\end{array}$ & & $\begin{array}{l}67 \\
44.1 \% \\
\end{array}$ & $\begin{array}{l}40 \\
26.3 \%\end{array}$ \\
\hline \multirow[b]{2}{*}{3} & \multirow{2}{*}{$\begin{array}{l}\text { I face technical problems when I use e- } \\
\text { learning. }\end{array}$} & \multicolumn{2}{|l|}{$P=15.8 \%$} & \multirow{2}{*}{$\begin{array}{l}28 \\
P=18.4 \%\end{array}$} & \multicolumn{2}{|c|}{$P=65.8 \%$} \\
\hline & & $\begin{array}{l}7 \\
4.6 \% \\
\end{array}$ & $\begin{array}{l}17 \\
11.2 \%\end{array}$ & & $\begin{array}{l}71 \\
46.7 \% \\
\end{array}$ & $\begin{array}{l}29 \\
19.1 \%\end{array}$ \\
\hline \multirow[b]{2}{*}{4} & \multirow[b]{2}{*}{$\begin{array}{l}\text { E-learning facilitates cheating and } \\
\text { plagiarism, especially English. }\end{array}$} & \multicolumn{2}{|l|}{$P=27.6 \%$} & \multirow[b]{2}{*}{$\begin{array}{l}54 \\
P=35.5 \%\end{array}$} & \multicolumn{2}{|c|}{$P=36.8 \%$} \\
\hline & & $\begin{array}{l}16 \\
10.5 \%\end{array}$ & $\begin{array}{l}26 \\
17.1 \%\end{array}$ & & $\begin{array}{l}40 \\
26.3 \%\end{array}$ & $\begin{array}{l}16 \\
10.5 \%\end{array}$ \\
\hline \multirow[b]{2}{*}{5} & \multirow{2}{*}{$\begin{array}{l}\text { I do not have a computer, so I find it } \\
\text { difficult to use e-learning. }\end{array}$} & \multicolumn{2}{|l|}{$P=57.2 \%$} & \multirow{2}{*}{$\begin{array}{l}37 \\
P=\mathbf{2 4 . 3} \%\end{array}$} & \multicolumn{2}{|c|}{$P=18.4 \%$} \\
\hline & & $\begin{array}{l}40 \\
26.3 \%\end{array}$ & $\begin{array}{l}47 \\
30.9 \%\end{array}$ & & $\begin{array}{l}19 \\
12.5 \%\end{array}$ & $\begin{array}{l}9 \\
5.9 \% \\
\end{array}$ \\
\hline \multirow[b]{2}{*}{6} & \multirow[b]{2}{*}{ It is expensive to buy a computer. } & \multicolumn{2}{|l|}{$P=48.6 \%$} & \multirow[b]{2}{*}{$\begin{array}{l}48 \\
P=31.6 \%\end{array}$} & \multicolumn{2}{|c|}{$P=19.7 \%$} \\
\hline & & $\begin{array}{l}30 \\
19.7 \%\end{array}$ & $\begin{array}{l}44 \\
28.9 \%\end{array}$ & & $\begin{array}{l}23 \\
15.1 \%\end{array}$ & $\begin{array}{l}7 \\
4.6 \%\end{array}$ \\
\hline \multirow[b]{2}{*}{7} & \multirow{2}{*}{$\begin{array}{l}\text { I have to go to a cybercafé because I do } \\
\text { not have internet access at home. }\end{array}$} & \multicolumn{2}{|l|}{$P=60.6 \%$} & \multirow{2}{*}{$\begin{array}{l}43 \\
P=\mathbf{2 8 . 3} \%\end{array}$} & \multicolumn{2}{|c|}{$P=11.2 \%$} \\
\hline & & $\begin{array}{l}41 \\
27.0 \% \\
\end{array}$ & $\begin{array}{l}51 \\
33.6 \% \\
\end{array}$ & & $\begin{array}{l}13 \\
8.6 \% \\
\end{array}$ & $\begin{array}{l}4 \\
2.6 \% \\
\end{array}$ \\
\hline \multirow[b]{2}{*}{8} & \multirow{2}{*}{$\begin{array}{l}\text { E-learning reduces face-to-face contact } \\
\text { among friends, but learning English } \\
\text { needs face-to-face conversations. }\end{array}$} & $\mathbf{P}=\mathbf{3 0 . 2 \%}$ & & & $P=40$ & \\
\hline & & $\begin{array}{l}16 \\
10.5 \%\end{array}$ & $\begin{array}{l}30 \\
19.7 \%\end{array}$ & $P=29.6 \%$ & $\begin{array}{l}40 \\
26.3 \%\end{array}$ & $\begin{array}{l}21 \\
13.8 \%\end{array}$ \\
\hline
\end{tabular}


( $P=$ percentage $)$

As can be seen in Table 4, the number-one problem students faced when they took e-Learning courses was due to slow-speed connectivity to the Internet. 107 out of 152 students (Item 2, P=70.4\%) could get access to the Internet at home, but they still found it fatiguing to follow the lessons since the Internet connectionwas poor. Besides, the second top disadvantage that the vast majority of the participants suffered from was about technical problems during the whole courses (Item 3, P=65.8\%). What is more, e-Learning courses might not suit many students' learning styles because of physical setting. Face-to-face interactions among students were under restriction, then it was not highly convenient for students to make one-on-one conversations compared to the real classroom setting (Item 8, P=40.1\%). Furthermore, over one third of the students agreed that e-Learning allowed cheating and plagiarism among learners (Item 4, $\mathrm{P}=36.8 \%$ ).

However, only $11.2 \%$ of the students found it difficult to get access to the Internet at home (Item 7). Moreover, on the very first day of getting familiar with e-Learning courses, only a tiny minority of the students encountered issues regarding teaching and learning methods, technology, etc. leading to frustration and disappointment (Item 1, P=13.8\%). In addition, fewer than 20 percent of the students did not have a computer (Item 5, $\mathrm{P}=18.4 \%$ ) and could not afford to purchase one because it was overpriced (Item $6, \mathrm{P}=19.7 \%$ ) whereas over half of the participants had their own computer.

All things considered, students might find it inconvenient to interact with teachers and friends when taking e-Learning courses was a new approach, so this might affect their expected learning outcomes. Additionally, many students at VLU found it hard to deal with some problems in regard to the Internet and technology.

The most considerable finding was that low-speed connectivity to the internet hindered students from performing well in the online lessons. This finding corroborates the ideas of Collins et al. (1997), Scott et al. (1999), Lewis (2000), Almosa (2002), Marc (2002), Klein and Ware (2003), Akkoyuklu and Soylu (2006), and Hameed et al. (2008) who suggest that the poor connection to the Internet made the learning process interrupted and time-consuming. Moreover, Al-Maqtri (2014), Laxmi (2017), and Henny (2020) found that or the unavailability of the Internet access or bad connection to the Internet prevented students from achieving the lesson objectives.

In this study, technical problems were also found to cause the disruption in the learning process. This finding is in agreement with Mohammed's (2020) finding which showed that technological challenges were the potential problems that students usually encountered.

The third most major drawback of using e-learning found in the current study was about the absence of face-to-face interactions. This also accords with our earlier observations, which showed that lack of face-to-face or psychological interactions could interfere with students' expected learning outcomes (Johan et al., 2013; Mohammed, 2020; Henny, 2020).

What is surprising is that most participants in this study could afford a computer. Therefore, bad financial condition was not a determining factor affecting VLU students' learning process. However, this finding does not support the ideas of Jenkinson (2009) who claims that students' poor financial condition is one of the crucial issues that make e-learning difficult for students.

\section{CONCLuSion}

\subsection{Summary of the Research Findings}

The investigation into the benefits and drawbacks of employing e-learning as a method of education has showed that several participants valued the advantages of e-learning. Particularly, students could study at their preferred time and place. It was easy for them to get access to the online materials, so they could get deeper understanding of the lessons. What is more, e-learning allowed students to study at their own pace. They, therefore, could review the lessons whenever they wanted so as to attain the objectives of each lesson. However, the study also found that students encountered some significant issues including low-speed connectivity to the Internet, technical problems, and loss of face-to-face interactions. The most interesting finding of the current study was that almost all participants could afford to purchase a computer, which was considered the major problem for the participants in previous studies as presented in the discussion section.

\subsection{Pedagogical Implications}


Non-English Majored Freshmen's Perspectives on Benefits and Challenges of Using E-Learning: a Study at Van Lang University

\subsubsection{For Students}

The evidence from this study suggests that students should prepare something in advance in order not to be disrupted in the learning process.

Firstly, in terms of Internet connection, high-speed package should be registered in order to minimize the risk of disconnection or low-speed connection.

Secondly, regarding technical problems, students can fix the problems themselves by watching videos on YouTube which provide the guidance on how to deal with technical faults when using a computer.

Thirdly, most students are afraid of turning on the camera when attending livestreaming classes and talking with their friends as well. Trying to be more confident and being well-prepared for the lessons can help students achieve the lesson objectives easily.

\subsubsection{For Teachers}

In respect of teachers, it is recommendable that teachers should be selective about the e-resources which provide students with accurate information and help them easily achieve the objectives of the lesson.

In addition, teachers are the ones who need to master the new technologies applied in teaching so as to support students when necessary. At the beginning of each e-learning course, a training session on what to do, how to solve the technical problems should be held in order to make sure that all the students are well-equipped with technical knowledge.

It is suggested that teachers should design more interactive activities when being together with the students in the livestreaming classes so that face-to-face interactions will no longer be a problem for the students.

\section{RECOMMENDATIONS FOR FURTHER RESEARCH}

It is recommended that further research be undertaken in the following areas:

More research is required to determine the efficacy of adopting e-learning among students by means of interviews to get more reliable and extensive data. It would also be worthwhile to compare the experiences of using e-learning among students from different educational institutions. By doing this we may construct an overview picture of the recent situation and then we might makeappropriate adjustments. It would be interesting to assess the effectiveness of using e-learning perceived by teachers within or out of a university.Further research might explore the teaching methods, strategies or applications effectively employed. Last but not least, further research in this field would be of great help in proposing possible solutions for the drawbacks of using e-learning.

\section{REFERENCES}

[1] Akkoyuklu, B., \&Soylu, M. Y. (2006). A study on studentse views on blended learning environment. Turkish Online Journal of Distance Education, 7(3).

[2] Al Maqtri, M. A. T. (2014). How effective is e-learning in teaching English? A case study. Journal of Education and Human Development,3(2), 647-669.

[3] Almosa, A. (2002). Use of Computer in Education, (2nd ed). Riyadh: Future Education Library.

[4] Babbie, E. (1989). Research methods for social work. California: Wadsworth.

[5] Bell, J. (2003). Doing your research project: a guide for first-time researchers in education and social science. England: Open University Press.

[6] Bogdan, R. C., \& Biklen, S. K. (1992). Qualitative research for education: an introduction to theory and methods. Boston: Allyn and Bacon.

[7] Borg, W. R., \& Gall, M. D. (1989). Educational research: an introduction. New York: Longman.

[8] Brown, C., Thomas, H., Merwe, A., \& van Dyk, L. (2008 ). The impact of South Africa's ICT infrastructure on higher education. In D. Remenyi, Proceedings of the3rd International Conference of ELearning. CapeTown, South Africa. Academic Publishing Limited.

[9] Bryman, A. (2001). Social research methods. New York: Oxford University Press.

[10] Čiarniené, R., \&Kumpikaite, V. (2005). Developing knowledge society: new approach to managerialeconomic preparation of specialists. Inžinerinèekonomika-Engineering economics, 1(41), 52-58. 
[11] Collins, J., Hammond, M., \& Wellington, J. (1997). Teaching and Learning with Multimedia. London: Routledge.

[12] Dublin, L. (2003). If you only look under the street lamps... Or nine e-Learning Myths. The eLearning developers journal. http://www.eLearningguild.com.

[13] Fry, K. (2001). E-learning markets and providers: some issues and prospects. Education Training, 233239.

[14] Gay, L. R. (1987). Educational research: competencies for analysis and application. London: Merrill Publishing.

[15] George, D., \& Mallery, P. (2003). SPSS for Windows step by step: A simple guide and reference. Boston, MA: Allyn \& Bacon.

[16] Ghaffari, A., \& Abbas, E. (2011). Improving education in adult through online learning. Life Science Journal, 8(3). Retrieved from http://www.lifesciencesite.com.

[17] Hameed, S., Badii, A., \& Cullen, A. J. (2008). Effective e-learning integration with traditional learning in a blended learning environment. European and Mediterranean conference on information system, 25-26.

[18] Henny, M. (2020). The use of e-learning to teach English in the time of the covid-19 pandemic. English Teaching and Linguistics Journal, 1(2), 49-55.

[19] Jenkinson, J. (2009). Measuring the effectiveness of educational technology: What are we attempting to measure? Electronic Journal of e-Learning, 7(3).

[20] Johan, E. L., Nur, N. S., Fazyudi, A. N., \&Kamarol, B. M. R. (2013). A study on the student's perspective on the effectiveness of using e-learning. Procedia - Social and Behavioral Sciences 123, 139-44.

[21] Khan, I. A. (2011). Effectiveness of e-learning for the teaching of English: A Study of Comparative Strategies. Advances in Language and Literary Studies, 7(3), 30-60.

[22] Klein, D.,\& Ware, M. (2003). E-learning: new opportunities in continuing professional development. Learned publishing, 16(1), 34-46.

[23] Laxmi, M. C. (2017). Student's perceptions of online learning platforms in EFL classroom. English Language Teaching and Technology Journal, 1(1), 22-30.

[24] Lewis, N. J. (2000). The Five Attributes of Innovative E-Learning.Policy and Research Publications Online Reports, 54(6), 47-51.

[25] Marc, J. R. (2002). Book review: e-learning strategies for delivering knowledge in the digital age. Internet and Higher Education, 5, 185-188.

[26] Maltz, L., Deblois, P., \& The EDUCAUSE Current Issues Committee. (2005). Top Ten IT Issues. EDUCAUSE Review, 40(1), 15-28.

[27] Mohammadi, N., Ghorbani, V., \& Hamidi, F. (2011). Effects of e-learning on Language Learning. Procedia Computer Science 3, 464-468.

[28] Mohammed, M. N. H. J. (2020). The Challenges and Prospects of Using E-learning among EFL Students in Bisha University. Arab World English Journal, 11(1), 124-137.

[29] Oblinger, D. G., \& Hawkins, B. L. (2005). The myth about E-learning. Educause review.

[30] Oppenheim, A. N. (1992). Questionnaire design, interviewing attitude measurement. London: Continuum.

[31] Rabah, M. (2005). E-learning, Jordan: Dar Almnahej Publisher.

[32] Radhakrishna, R. B. (2007). Tips for developing and testing questionnaires/instruments. Journal of Extension, 45(1). Retrieved from http://www.joe.org/joe/2007february/tt2.php.

[33] Scott B., Ken C. H., \& Edwin M. G. (1999). The effects of internet-based instruction on student learning. Journal of Asynchronous Learning Network, 3(2), 98-106.

[34] Seliger, H. W., \&Shohamy, E. (1997). Second language research methods. New York: Oxford University Press.

[35] Smith, M. E. (1994). Management research: an introduction. London: Sage.

[36] Zhang, D., ZHOU, L., BrIggs, R. \&Nunamaker, J. (2006). Instructional video in e-learning: Assessing the impact of interactive video on learning effectiveness. Information \& Management, 43(1), 15-27

[37] Züll, C. (2016). Open-Ended Questions. GESIS Survey Guidelines. Mannheim, Germany: GESIS Leibniz Institute for the Social Sciences. doi: 10.15465/gesis-sg_en_002 
Non-English Majored Freshmen's Perspectives on Benefits and Challenges of Using E-Learning: a Study at Van Lang University

\section{APPENDIX}

\section{QUESTIONNAIRE}

Dear student,

This questionnaire aims at exploring your perspective regarding the effectiveness of adopting elearning for the general English course including advantages, disadvantages, and suggestions for improvement. Your contribution will be a great help to my research. There are no right or wrong answers to this questionnaire. Your personal information will be kept confidential and anonymous. Please kindly take some time to honestly complete this questionnaire by putting a cross (x) in the appropriate box.

\section{PART 1: Personal Information}

\section{Please put the mark $(X)$ in the place that suits your case:}
1/ Gender:
$\square$ male
$\square$ female

2/ How technological are you?
weak
$\square \operatorname{good}$
very good
excellent

3/ Do you have a computer at home?

$\square$ yes

$\square$ no

4/ Do you have internet access at home?

$\square$ yes

$\square$ no

5/ Where do you prefer to use the internet for e-learning?

$\square$ at home $\quad \square$ at the university $\square$ at an internet café

6/ Do you agree with those who say that e-learning is a waste of time?

$\square$ yes

$\square$ no

\section{PART II: Advantages and Disadvantages of E-learning}

Please indicate your opinion after each statement by putting $(X)$ in the box which best expresses your perspective.

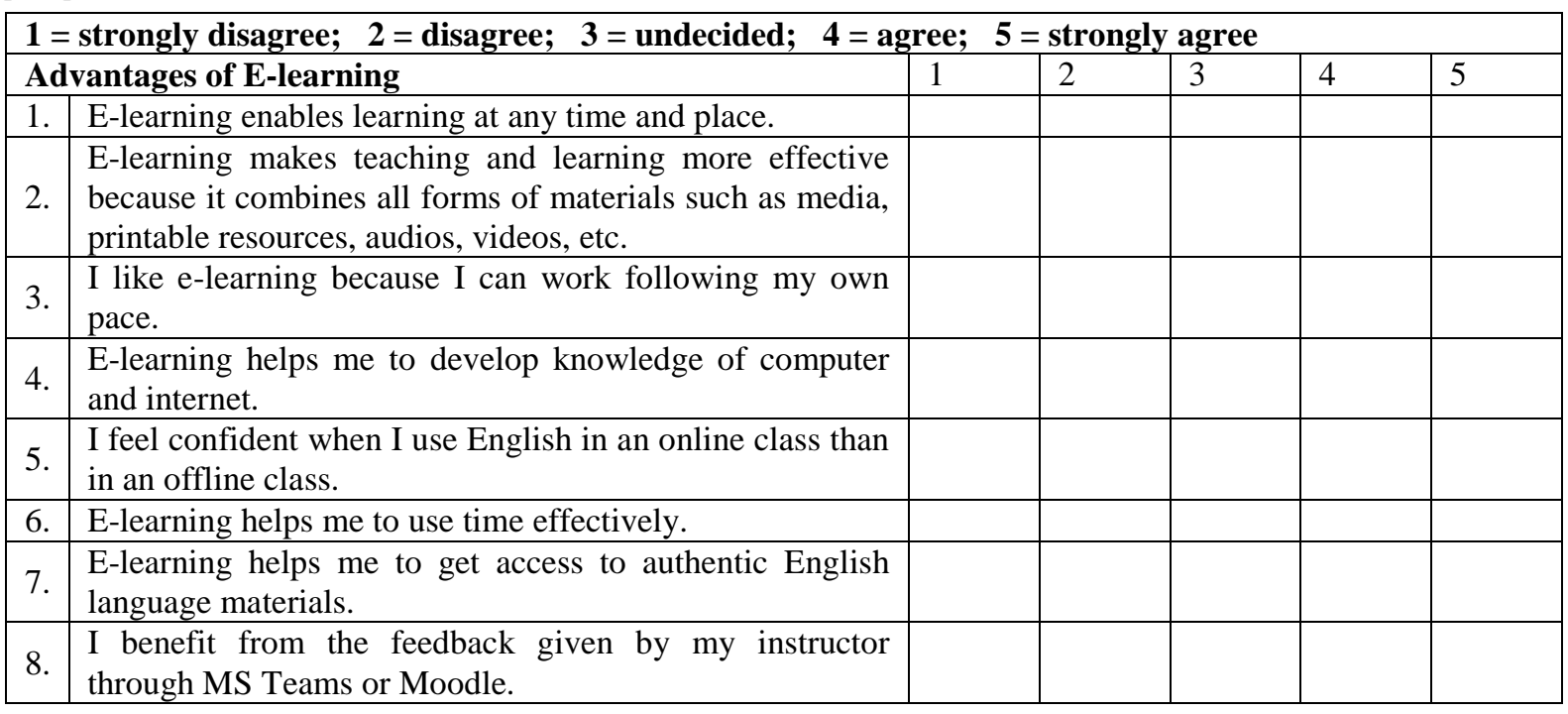

\begin{tabular}{|l|l|l|l|l|l|l|}
\hline \multicolumn{1}{|l|}{$\mathbf{1}=$ strongly disagree; 2 = disagree; 3= undecided; 4= agree; 5= strongly agree } \\
\hline Disadvantages of E-learning & 1 2 & 2 & 4 & 5 \\
\hline 9. & $\begin{array}{l}\text { E-learning is difficult to handle and therefore frustrating } \\
\text { to use. }\end{array}$ & & & & \\
\hline 10. & $\begin{array}{l}\text { Slow internet connectivity is a major problem I face } \\
\text { when using e-learning. }\end{array}$ & & & & \\
\hline 11. & I face technical problems when I use e-learning. & & & & & \\
\hline 12. & E-learning facilitates cheating and plagiarism. & & & & & \\
\hline 13. & $\begin{array}{l}\text { I do not have a computer, so I find it difficult to use e- } \\
\text { learning. }\end{array}$ & & & & \\
\hline
\end{tabular}


Non-English Majored Freshmen's Perspectives on Benefits and Challenges of Using E-Learning: a Study at Van Lang University

\begin{tabular}{|c|l|l|l|l|l|l|}
\hline 14. & It is expensive to buy a computer. & & & & & \\
\hline 15. & $\begin{array}{l}\text { I have to go to a cybercafé because I do not have internet } \\
\text { access at home. }\end{array}$ & & & & & \\
\hline 16. & E-learning reduces face-to-face contact among friends. & & & & & \\
\hline
\end{tabular}

\section{Thank you for your great support!}

\section{AUTHOR'S BIOGRAPHY}

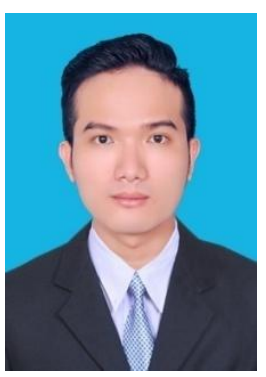

Mr. Chau Thanh Nha, is currently a full-time lecturer of English at Van Lang University (VLU). Besides, he had over two years' experience in teaching English skills to English majors and non-English majors at The Saigon International University from August 2016 to October 2018. More than that, he used to English at Duong Minh Language School from 2016 to 2020. He has extensive experience in working with EFL students of all ages including kids, teenagers and adults. He earned his Master's Degree in English Language at Ho Chi Minh City University of Technology in July 2019. His academic areas of interest mostly lie in TESOL methodology, language skills, and applied linguistics.

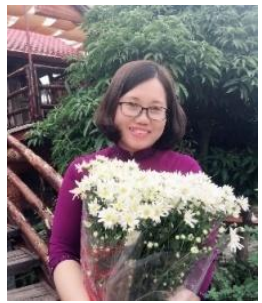

Ms. Hoang ThiHoa, is currently a full-time lecturer of English at Van Lang University (VLU). She obtained her master's degree in TESOL at University of Languages and International Studies (ULIS), Vietnam National University (VNU), Hanoi. She had over 16 years' experience in teaching English to English majors and non-English majors at Luong The Vinh university and Vocational Training College No.20, MOD. She had the wonderful opportunity to teach a diverse group of students, and as a result, she developed highly effective teaching techniques and instructional methods, which have allowed her to educate all styles of learners. Within her career, she had leadership experience as the Head of Faculty of Foreign Languages at Luong The Vinh university.

Citation: Chau Thanh Nha, M.A., Hoang ThiHoa, M.A. "Non-English Majored Freshmen's Perspectives on Benefits and Challenges of Using E-Learning: a Study at Van Lang University." International Journal on Studies in English Language and Literature (IJSELL), vol 9, no. 9, 2021, pp. 56-68. doi: https://doi.org/10.20431/2347-3134.0909006.

Copyright: () 2021 Authors. This is an open-access article distributed under the terms of the Creative Commons Attribution License, which permits unrestricted use, distribution, and reproduction in any medium, provided the original author and source are credited. 